\title{
The Impact of European Integration on Wage Differentials in the Bavarian-Czech Border Region
}

\author{
Michael Moritz ${ }^{\#}$ \\ Institute for Employment Research, Nuremberg
}

\begin{abstract}
In the process of European integration labour markets are assumed to be affected disproportionately in regions bordering on new EU member countries. With respect to wage differentials, compared to interior regions, low-skilled workers there are according to the Feenstra-Hanson model predicted to suffer notably from increasing trade and the relocation of production activities to low-wage countries, while high-skilled workers should benefit from the increasing market potential. Using data from the IAB employment subsample (IABS) and the employment register $(\mathrm{BeH})$ I shed light on the development of the wages for workers in eastern Bavaria compared to other western German districts. Conducting regressions separately for every year and a fixed-effects approach I come to surprising results: while in the early years after the fall of the Iron Curtain a catching-up process set in for employees in eastern Bavaria, the trend reverses after 1995 and the wage gap deepens again.
\end{abstract}

Zusammenfassung: Die Arbeitsmärkte in Grenzregionen zu den mittelosteuropäischen EUMitgliedern sind durch die wirtschaftliche Integration Europas besonders betroffen. Durch die geographische Nähe sollten sich dort die relativen Änderungen in der Arbeitsnachfrage überdurchschnittlich auswirken. Dem Feenstra-Hanson-Modell zufolge verlieren geringqualifizierte Arbeitnehmer im Grenzland überproportional, während Hochqualifizierte die Gewinner der Handelsliberalisierung sind. Auf Basis der Daten der IAB-Beschäftigtenstichprobe und der Beschäftigten-Historik schätze ich die Lohndifferentiale zwischen Arbeitnehmern in der Grenzregion Ostbayern und dem restlichen westdeutschen Bundesgebiet. Die Ergebnisse überraschen: während es Anfang der 1990er Jahre zu einem Aufholprozess in Ostbayern kommt, dreht sich der Trend ab 1995 und der Lohnabstand wächst wieder.

Keywords: regional labour markets, border regions, international trade, wage structure

JEL-classification: J31, R23, F16

Acknowledgements: I would like to thank the participants of the conference "Außenwirtschaft in Zeiten der Globalisierung" of the German Council for Social and Economic Data (RatSWD) and the seminars of the IAB-WiSo Graduate Program, Nuremberg, where earlier versions of this paper were presented, for helpful comments. I am particularly grateful to Joachim Möller and Uwe Blien for very valuable advice, comments and suggestions. Any errors, however, remain my sole responsibility.

\footnotetext{
\# Correspondence to: Michael Moritz, Institute for Employment Research, Regensburger Str. 104, D-90478 Nuremberg, Germany, E-mail: michael.moritz@iab.de, phone: +49 (0)911 179-2133.
} 


\section{Introduction}

In the course of globalisation and the EU enlargement process the labour markets in western European countries have to face intense cost pressure. Especially the population at the immediate frontier between old and new EU member states is affected by fundamental changes in the economic framework. The unexpected fall of the Iron Curtain in 1989 meets the criteria of a natural experiment. Though border regions should profit due to increasing trade possibilities in the long run, they have to cope with adjustment problems in particular on the labour market. Although free movement of labour and freedom of services is still restricted in a transition period not exceeding 2011, the districts in eastern Bavaria close to the Czech Republic have to bear the growing import competition from the neighbouring country. Against this background the question arises, what impact the increasing economic integration had on the development of wages in the districts close to the border.

While traditional trade models deal with the distribution of horizontal production across countries (models by Ricardo, Heckscher-Ohlin, Stolper-Samuelson theorem), new trade theory tries to explain the phenomenon of intra-industrial trade and the fragmentation of production. One of the most important models from this group of the literature is the Feenstra-Hanson model, which was developed in the course of the increasing outsourcing activities from the United States to Mexico. In the model developed by Feenstra/Hanson (1996) a single manufactured good is produced in two countries (home and foreign, $\mathrm{i}=1,2$ ) from a continuum of intermediate inputs using unskilled labour $\left(L_{i}\right)$, skilled labour $\left(H_{i}\right)$ and capital $\left(K_{i}\right)$. The factor prices are given by the wage for unskilled labour $w_{i}$, the wage for skilled labour $q_{i}$ and the

rental on capital $r_{i} . \mathrm{z} \in[0,1]$ denotes the many different activities necessary for the production of a final good whose production needs no additional input of labour or capital. A higher value of $z$ is equivalent to an input that uses skilled labour more intensively. It is assumed that unskilled labour is relatively scarce and skilled labour relatively abundant in the home country. Therefore unskilled labour is relatively more expensive at home than abroad. $z^{*}$ denotes the equilibrium value, i.e. the critical value regarding the fragmentation of production between the home and the foreign country. Since according to the above assumption the wage of skilled employees is relatively lower in the home country, all activities $z^{\prime}>z^{*}$ can be produced advantageously at home. On the other hand all activities $\mathrm{z}^{\prime}<\mathrm{z}^{*}$ can be produced at a cheaper rate in the foreign country. As a consequence the foreign country specialises in activities $\left[0, z^{*}\right)$, whilst the home country specialises in activities $\left(z^{*}, 1\right]$. The assumption that the rental on capital $r$ is lower in the home country $\left(r_{1}<r_{2}\right)$, reflects the relative abundance of 
capital at home. Allowing for capital mobility between the two countries, capital will move abroad, so that $K$ decreases at home and increases abroad. This results in rising capital costs in the home country, while in the foreign country the capital rent will shrink. Consequently, due to the modified cost structure, the equilibrium value of $z$ increases, i.e. the foreign country specialises in an expanded range of activities, while the home country specialises in a contracted range of activities. This has the following implications regarding the demand for labour: the production activities which are outsourced from the home to the foreign country use skilled labour less intensively than the activities which still are produced at home. Hence the relative demand for unskilled labour drops in the home country, the relative demand for skilled labour rises. In the foreign country the allured activities use relatively more skilled labour than the hitherto performed activities, leading to a growing demand for skilled labour there, too. Unlike in the Heckscher-Ohlin-Samuelson framework the relative wages of skilled labour rise in both countries.

The essential conclusion of this theoretical model is that even without explicit consideration of border regions it can be derived that, in general, in the borderland labour market effects of economic integration are especially large. Low-skilled workers are supposed to lose out above-average there, while high-skilled workers should especially profit in districts close to the new markets. This standpoint is reflected in the European Commission's report on EU-15 border regions (European Commission 2001: 10): "In general, human capital-intensive and technologically advanced sectors in the border regions are likely to benefit from enlargement, while labour-intensive sectors are likely to face increased competition from cheap labour."

As in the theoretical field for the matter of empirics the studies by Feenstra and Hanson constitute substantial contributions in favour of the research on border regions. In the case of Mexico the effects of trade liberalisation since the mid of the 1980s are analysed in detail. The empirical results of Hanson (1996a, 1996b) suggest that the expansion of export manufacturing in the Mexican border region significantly contributed to the employment growth in U.S. border manufacturing industries. In recent years some papers provided results for the 1990s which challenge the conclusion of Feenstra and Hanson that outsourcing is the driving force for increasing wage differentials in developing countries. Chiquiar (2004) and Airola/Juhn (2005) find evidence that between 1990 and 2000 demand for skilled labour increased at a much slower rate in regions highly integrated with the U.S. compared to other Mexican regions. Also with respect to European economic integration studies refer to the Feenstra-Hanson model. Examining nationwide wage differentials Skuratowicz (2005) finds a growing wage gap between high- and low-skilled workers in Poland. It is quite evident that 
skill upgrading took also place in the EU accession countries (Bruno et al. 2004). In one of the rare micro-level studies Geishecker/Görg (2003) estimate the effects of international outsourcing on the wages of different skill groups by allowing for individual fixed effects. They find evidence for low-skilled workers being the losers of globalised production, since trade and outsourcing reduced the real wages in this skill group by up to $1.8 \%$. On the other hand, high-skilled workers benefited from the new trade opportunities by increasing wages up to 3.3\%. These results are in line with the findings of Geishecker (2002) stating that with nearly stable relative wages in the 1990s, the decline of the relative demand for low-skilled labour can be explained up to $24 \%$ by international outsourcing. Unfortunately, in many cases the analyses are related to whole countries, while there is no reference to regional information, often due to a lack of available data. Though it is beyond all question that skill premiums went up in Western as well as in Eastern European countries, the main cause is still controversial. Since it is above all the effects of free trade and international outsourcing on the development of wage differentials that are disputed, focusing on border regions can contribute to shed light on this topic.

In this paper I highlight the specific situation of the Bavarian-Czech cross-border labour market. While Moritz/Gröger (2007) only use a two percent random sample of all employees not finding significant results I estimate wage effects on the basis of a larger dataset containing all employees subject to social insurance contribution in eastern Bavaria. The remainder of the paper is structured as follows: section 2 provides an introduction of my data source. In section 3 I describe the estimation methods and the results. Section 4 concludes.

\section{Data and Basic Definitions}

I use micro data from the weakly anonymous version of the IAB Employment Sample (IABS) for the years from 1980 to 2001, which are provided by the Institute for Employment Research (IAB) and contain information about a two percent random sample of all employees covered by the social security system (for a description of the dataset see Hamann 2005). In order to avoid that observations for the border region are too few and insufficient for robust estimates I include an extract from the employment register (Beschäftigtenhistorik $\mathrm{BeH}$ ), which covers all observations in the eastern Bavarian border region (i.e. 100\% instead of 2\%). For all estimations I eliminate apprentices, marginal part-time and part-time workers, homeworkers and all observations where information about education and/or professional status is missing, from the data. I concentrate on full-time employees, aged 16 to 65, who are at least 
in one year employed on June 30 (the reference date). I distinguish between the following three skill groups of workers (table 1):

Table 1: Classification of German skill groups

\begin{tabular}{|l|l|}
\hline Skill group & Qualification \\
\hline low-skilled & $\begin{array}{l}\text { people with no occupational qualification regardless of the educational } \\
\text { level reached, i.e. with or without a certificate of upper secondary } \\
\text { education (Abitur) }\end{array}$ \\
\hline skilled & $\begin{array}{l}\text { people with an occupational qualification whether or not they have a } \\
\text { certificate of upper secondary education (Abitur) }\end{array}$ \\
\hline high-skilled & $\begin{array}{l}\text { people with upper secondary education and a degree from a university } \\
\text { or polytechnic }\end{array}$ \\
\hline
\end{tabular}

Table 2: Regional classification scheme based on BBR classification

\begin{tabular}{|l|c|l|}
\hline Structural region type & District type & Description of region type (BBR) \\
\hline $\begin{array}{l}\text { Regions with large ag- } \\
\text { glomerations (basic type 1) }\end{array}$ & BBR 1 & Core cities \\
\cline { 2 - 3 } & BBR 2 & $\begin{array}{l}\text { Highly urbanised districts in regions } \\
\text { with large agglomerations }\end{array}$ \\
\cline { 2 - 3 } & BBR 3 & $\begin{array}{l}\text { Urbanised districts in regions with } \\
\text { large agglomerations }\end{array}$ \\
\cline { 2 - 3 } & BBR 4 & $\begin{array}{l}\text { Rural districts in regions with large } \\
\text { agglomerations }\end{array}$ \\
\hline $\begin{array}{l}\text { Regions with features of } \\
\text { conurbation (basic type 2) }\end{array}$ & BBR 5 & $\begin{array}{l}\text { Central cities in regions with interme- } \\
\text { diate agglomerations }\end{array}$ \\
\cline { 2 - 3 } & BBR 6 & $\begin{array}{l}\text { Urbanised districts in regions with } \\
\text { intermediate agglomerations }\end{array}$ \\
\cline { 2 - 3 } & BBR 7 & $\begin{array}{l}\text { Rural districts in regions with inter- } \\
\text { mediate agglomerations }\end{array}$ \\
\hline \multirow{2}{*}{$\begin{array}{l}\text { Regions of rural character } \\
\text { (basic type 3) }\end{array}$} & BBR 8 & Urbanised districts in rural regions \\
\cline { 2 - 3 } & BBR 9 & Rural districts in rural regions \\
\hline
\end{tabular}

Source: Federal Office for Building and Regional Planning (Bundesamt für Bauwesen und Raumordnung BBR).

According to the regulation regarding employment permits for foreign commuters in German border regions (Anwerbestoppausnahmeverordnung ASAV 1997) the Bavarian borderland consists of the eastern parts of the regions of Oberfranken (Upper Franconia), Oberpfalz (Upper Palatinate) and Niederbayern (Lower Bavaria) including the university towns of Bayreuth and Passau and the towns with polytechnics (Fachhochschulen) Hof, Weiden, Amberg and Deggendorf (15 districts and 7 autonomous municipal authorities, figure 1). In contrast to the 
border region in ASAV, § 6 para. 1 my analysis covers the city and the district of Regensburg. Taking into account the differences between urban and rural areas I use the classification scheme of the Federal Office for Building and Regional Planning (Bundesamt für Bauwesen und Raumordnung BBR), which differentiates between regions with large agglomerations (BBR 1-4), regions with features of conurbation (BBR 5-7) and regions of rural character (BBR 8-9) (table 2). As control group I use the observations only from the remaining western German districts (without Berlin), since the inclusion of data from the eastern German states (which are available from 1992 onwards) would lead to biased results.

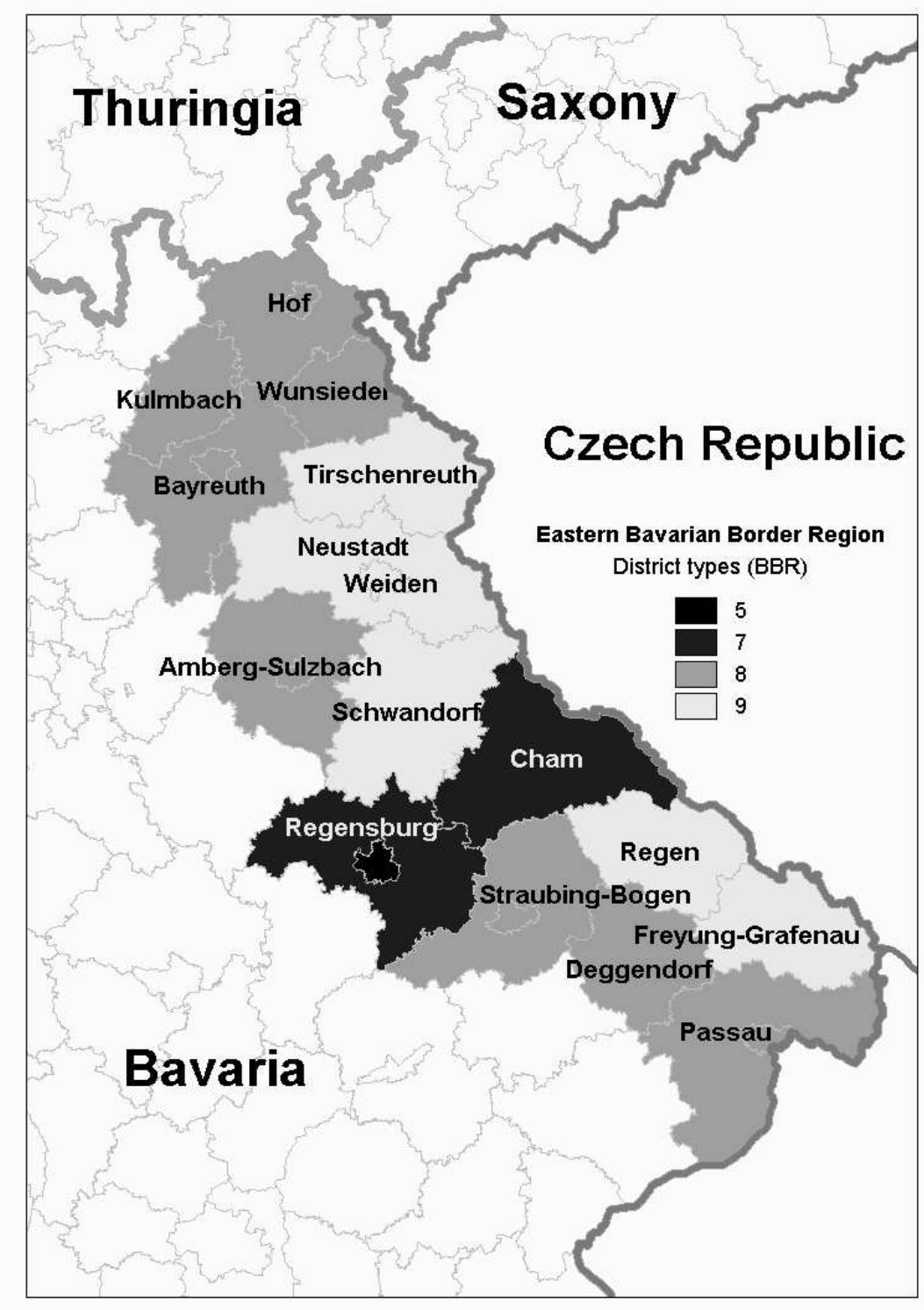

Figure 1: Eastern Bavarian border region 


\section{Econometric Analysis of Wage Differentials}

\subsection{Separate Regressions for Each Year}

The aim of my analysis is to estimate whether the opening of the border between Germany and the Czech Republic had a significant effect on the development of employess' wages in the eastern Bavarian borderland compared to employees in other western German districts. Firstly, the development of relative wage differentials can be estimated in every year by conventional regression analysis. Focusing on full-time working employees I estimate a Mincerian wage equation (Mincer 1974) by running cross-sectional regressions for each year between 1980 and 2001 separately. I split the dataset into subsamples according to the skill and sex groups. ${ }^{1}$ The estimation equation takes the following form:

$$
\begin{aligned}
\ln \text { WAGE }_{i} & =\alpha+\beta_{1} \text { EXPER }_{i}++\beta_{2} \text { EXPER }_{i}^{2}+\sum_{j=1}^{J=3} \gamma_{j} \text { BBR }_{j i}+\sum_{k=1}^{K=27} \delta_{k} \text { DWZWG }_{k i} \\
& +\lambda \text { FOREIGN }_{i}+\tau \text { BORREG }_{i}+\phi \text { BORREG }^{*} \text { FOREIGN }_{i}+\varepsilon_{i}
\end{aligned}
$$

For a detailed definition of the variables see table 3. The dependent variable $\ln W A G E_{i}$ denotes the logarithm of individual i's daily wage. Contrary to the regressions in Moritz/Gröger (2007) I do not estimate a Tobit model, but use wages that are in the case of censoring at the upper ceiling in the German social contribution system imputed on the basis of Tobit estimates of the distribution parameters (Gartner 2005), so that I can then apply the standard OLS method. In addition to the variables controlling for the potential experience (EXPER, EX$\left.P E R^{2}\right)$ I use dummies for the district types $(B B R)$ and the industries $(D W Z W G) .^{2}$ The branches of economic activity are not aggregated into 16 industries, but are available on the basis of a 3-digit code (WZ 73). I transform this very detailed classification into a scheme of 28 industries. In order to avoid estimations for a reference group of job entrants I include only individuals with at least five years of work experience. Since the district types 1-4 and 6 do not appear in the border region I exclude observations of these districts from the estimation. Moreover, I include a dummy variable for nationality (FOREIGN), which equals one if the employee is not German and zero otherwise. The coefficient of BORREG $\tau$, which I'm mostly interested in, estimates the wage effect (as \%) for German employees of the respective skill

\footnotetext{
${ }^{1}$ Since I use all observations for the border region from the employment register and only a $2 \%$ sample of observations in the non-border region I weight the observations adequately to their representativeness.

2 The workers' potential on-the-job experience (EXPER) is measured in years as age minus average duration of education minus six. I impose 10 years as the average duration of education for low-skilled workers without upper secondary education, 13 years for low-skilled workers with upper secondary education, 12.5 and 15 years respectively for skilled workers, 16 years for high-skilled workers holding a degree from a polytechnicand 18 years for high-skilled university graduates.
} 
and sex group in the border region compared with the national level. According to my hypothesis I expect decreasing values of $\tau$ for low-skilled workers and increasing values for skilled and high-skilled workers for the years after 1989. In order to control for the Czech commuters who are allowed to work in the Bavarian borderlands, I interact the nationality dummy with the border region dummy (BORREG*FOREIGN). The coefficient of this variable measures the wage effect of foreigners in the border region relative to foreigners in the rest of the country.

Table 3: Variables of the wage equation

\begin{tabular}{|l|l|}
\hline ln WAGE & logarithm of individual wage \\
\hline EXPER $(\geq 5)$ & potential job experience \\
\hline EXPER $^{2}$ & potential job experience ${ }^{2} / 100$ \\
\hline BBR $^{*}$ & dummies for BBR district types 5,7 and 8 \\
\hline DWZWG* & dummies for industries $1-27$ \\
\hline FOREIGN & dummy for foreign workers \\
\hline BORREG & dummy for border region \\
\hline BORREG*FOREIGN & interaction term of BORREG and FOREIGN \\
\hline cons. & constant \\
\hline
\end{tabular}

The estimation results of the control variables are sensible. The coefficient of the variable controlling for foreign workers exhibits all along the observation period negative values for all male skill groups and for low-skilled female workers. This means, that foreigners belonging to these groups earn less than the relevant domestic German workers. Positive wage differentials for non-Germans are identified for female skilled workers in the 1990s and in some years for female high-skilled workers. One additional year of potential experience yields in the first instance a significant wage increase, but the benefit decays over time (coefficients of $\left.E X P E R+, E X P E R^{2}-\right)$. The significant coefficient values for most of the dummies for district types and industries provide evidence for an agglomeration wage premium as well as for inter-industrial wage differentials.

Concerning the border region dummy I obtain the following results for the coefficient $\tau$ : in the case of domestic low-skilled workers an interesting difference between males (figure 2a) and females (figure 2b) is observable. In the 1980s male low-skilled employees in the eastern Bavarian border region earn about $5 \%$ less. This wage differential considerably narrows in the beginning of the 1990s to around $-3 \%$. Until the end of the decade the wage gap widens again 
approaching the original level of $-5 \%$. In contrast to this surprising development there is no similar trend for low-skilled female workers in the border region. Starting from a far smaller wage gap of approximately $-2 \%$ the difference increases in the 1980 s to about $-4 \%$. This level stabilises during the 1990s with only one negative outlier in 1999.
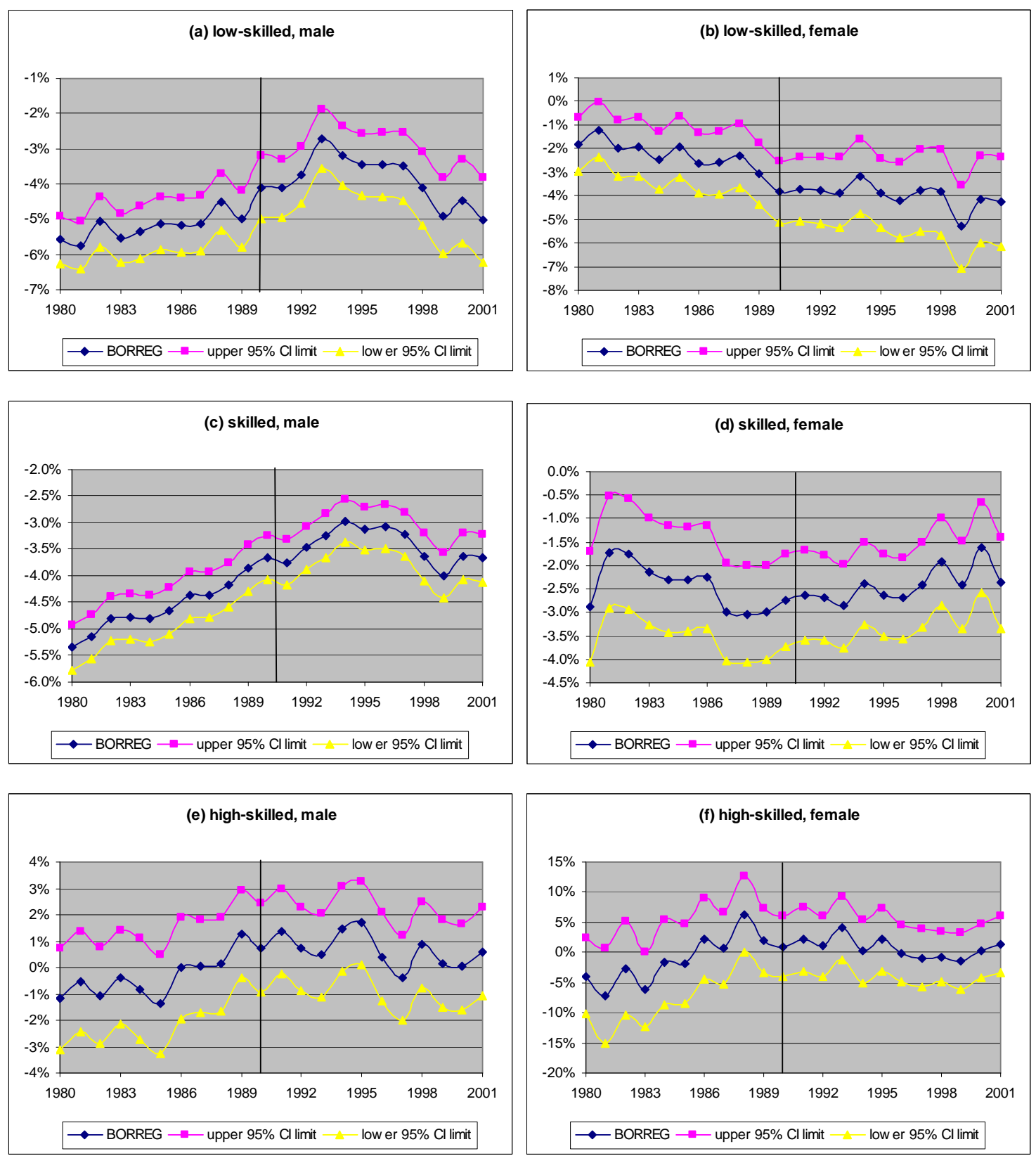

\section{Figure 2: Gender-specific wage effect for German employees in eastern Bavaria (as \%, 1980-2001)}

Source: Own calculations using the weakly anonymous version of the IABS + BeH extract.

Notes: In the case of censoring, wages are calculated in the framework of an imputation procedure using Tobit estimation method; Regression with heteroskedasticity-robust standard errors; ******* significant at the 10/5/1 percent level. 
Regarding skilled employees a general catching-up process in eastern Bavaria is clearly evident in the estimates, but interestingly, again only for male employees (figure 2c). Earning nearly $5.5 \%$ less in 1980 the differential becomes continuously smaller until the mid 1990s at a level of about $3 \%$. Then, similar to the trend for low-skilled male workers, the graph turns to a deeper wage gap of around $4 \%$ in 1999 with a slight recovery in the following two years. For female skilled workers the picture is again completely different (figure 2d). Relative wage losses for employees in the borderlands in the 1980s (from $-2 \%$ to $-3 \%$ ) are succeeded by making them up in the 1990s (from $-3 \%$ to $-2 \%$ ).

As far as high-skilled workers are concerned, the distinctively smaller number of observations poses a problem (apparent in the figures through the huge confidential bounds). Male highskilled workers in eastern Bavaria (figure 2e) earn about $1 \%$ below average until the mid 1980s. In the following ten years the wage differential is positive and then oscillates around the $0 \%$ line. Female high-skilled workers in the border region obviously catch up in the 1980s from below average to above average values. In the 1990s the wage level stabilises around the reference value for western Germany (figure $2 \mathrm{f}$ ).

\subsection{Panel: Fixed Effects}

In the previous subsection I splitted the dataset according to the years from 1980 to 2001 and estimated separately the wage effect in the border region. Since this method has some drawbacks I also apply a fixed-effects approach and compare the results. In order to account for the time structure of the data I now use the whole dataset across the years. Since some individuals are observed not only in one period the data have the structure of an unbalanced panel, which entails some advantages. Compared to a series of cross sections the explanatory variables now vary over two dimensions (individuals and time). Moreover, having a larger sample size in only one equation usually leads to more accurate estimators. More intuitively, the data should provide better information since the same individuals are repeatedly observed (Verbeek 2004). Furthermore, the above applied estimation method does not control for unobserved heterogeneity. Individuals exhibit characteristics which are hardly observable. This fact poses a problem if these attributes have an effect on the outcome variable and in addition are correlated with an explanatory variable, i.e. the estimate of this variable will be biased due to endogeneity. In the border region scenario, for instance, employees living there could have characteristics, e.g. regarding career planning and motivation that lead to a lower wage. Omitting these factors in the regression would yield a biased estimate for the variable BORREG, which then captures this effect. In order to control for unobserved heterogeneity I apply a 
fixed-effects approach, i.e. I mitigate the omitted variable bias by replacing the constant in the wage equation in the previous subsection with a fixed effect $\pi_{\mathrm{i}}$, which captures time-invariant characteristics of the individuals. In this case, the coefficient of the variable BORREG reflects the basic wage differential of employees in the eastern Bavarian border region in 1980. It is important to mention that this variable in the fixed effects regression only estimates the effect for movers from the non-border into the borderland against the movers in the opposite direction. In order to reflect the wage increases over time I include a set of time dummies into the wage equation above, s.th. YEAR1981 = 1 if $\mathrm{t}=1981$ and so on. While the year 1980 constitutes the base period, the time dummies capture in each year the general trend which does not vary between the individuals. Furthermore I generate interaction terms between the different years and the border region dummy (BORREG*YEAR1981 etc.). As these interaction terms control for the difference (over time) in the difference (wage gap in the border region), the coefficients $\omega_{1}, \ldots, \omega_{21}$ represent the difference-in-difference estimators (Wooldridge 2003). The coefficient of an interaction term in a specific year expresses the change in the wage differential of the border region relative to the rest of the country.

A Hausman test rejects in all cases the hypothesis that with respect to a random-effects model the differences in the estimated coefficients are not systematic, i.e. the fixed-effects model is favoured. Table 4 shows the wage differentials in the reference year 1980 and figure 3 the development in the following years. The results for BORREG and the interaction terms are quite plausible. In all cases the coefficient for BORREG exhibits a negative sign, in this case with significant values only for all male subgroups. Comparing the course of the graph to the gradient in the previous regressions, there is one striking difference: for all male and female subgroups the wage gap at the end of the observation period (in 2001) is larger than at the beginning (in 1980). Regardless of the trend starting already in the 1980s or be it a reversal in the mid 1990s the decline is more substantial than in my preceding results. This means that controlling for idiosyncratic characteristics of the individuals the relative wages in the eastern Bavarian border region are decreasing, though not everywhere significantly. It is interesting that the catching-up process for male low-skilled and skilled workers is also confirmed using this estimation method. Summarising the results, the trend from the mid 1990s onward seems generally unfavourable for eastern Bavaria. 
Table 4: Basic wage differential for German employees in fixed effects estimations

\begin{tabular}{|c|c|c|c|c|c|c|}
\hline & \multicolumn{2}{|l|}{ BORREG (low-skilled) } & \multicolumn{2}{c|}{ BORREG (skilled) } & \multicolumn{2}{c|}{ BORREG (high-skilled) } \\
\hline sex & Coef. $\tau$ & Std. Err. & Coef. $\tau$ & Std. Err. & Coef. $\tau$ & Std. Err. \\
\hline male & $-0.0816^{* * *}$ & 0.0135 & $-0.0445^{* * *}$ & 0.0056 & $-0.0949 * * *$ & 0.0308 \\
\hline & $\begin{array}{l}\mathrm{N}=1,579,214 \\
\mathrm{n}=256,058\end{array}$ & $\mathrm{R}^{2}=0.7573$ & $\begin{array}{l}\mathrm{N}=5,610,951 \\
\mathrm{n}=647,543\end{array}$ & $\mathrm{R}^{2}=0.7586$ & $\begin{array}{l}\mathrm{N}=362,935 \\
\mathrm{n}=60,526\end{array}$ & $\mathrm{R}^{2}=0.5692$ \\
\hline female & -0.0174 & 0.0438 & -0.0205 & 0.0156 & -0.0835 & 0.0767 \\
\hline & $\begin{array}{l}\mathrm{N}=1,315,872 \\
\mathrm{n}=212,503\end{array}$ & $\mathrm{R}^{2}=0.6312$ & $\begin{array}{l}\mathrm{N}=2,108,504 \\
\mathrm{n}=353,526\end{array}$ & $\mathrm{R}^{2}=0.5791$ & $\begin{array}{l}\mathrm{N}=73,356 \\
\mathrm{n}=18,321\end{array}$ & $\mathrm{R}^{2}=0.5197$ \\
\hline
\end{tabular}

Source: Own calculations using the weakly anonymous version of the IABS + BeH extract.

Notes: In the case of censoring, wages are calculated in the framework of an imputation procedure using Tobit estimation method; regression with heteroskedasticity-robust standard errors; $* * * / * * *$ significant at the $10 / 5 / 1$ percent level; N: Number of observations, n: number of groups; $\mathrm{R}^{2}$ within
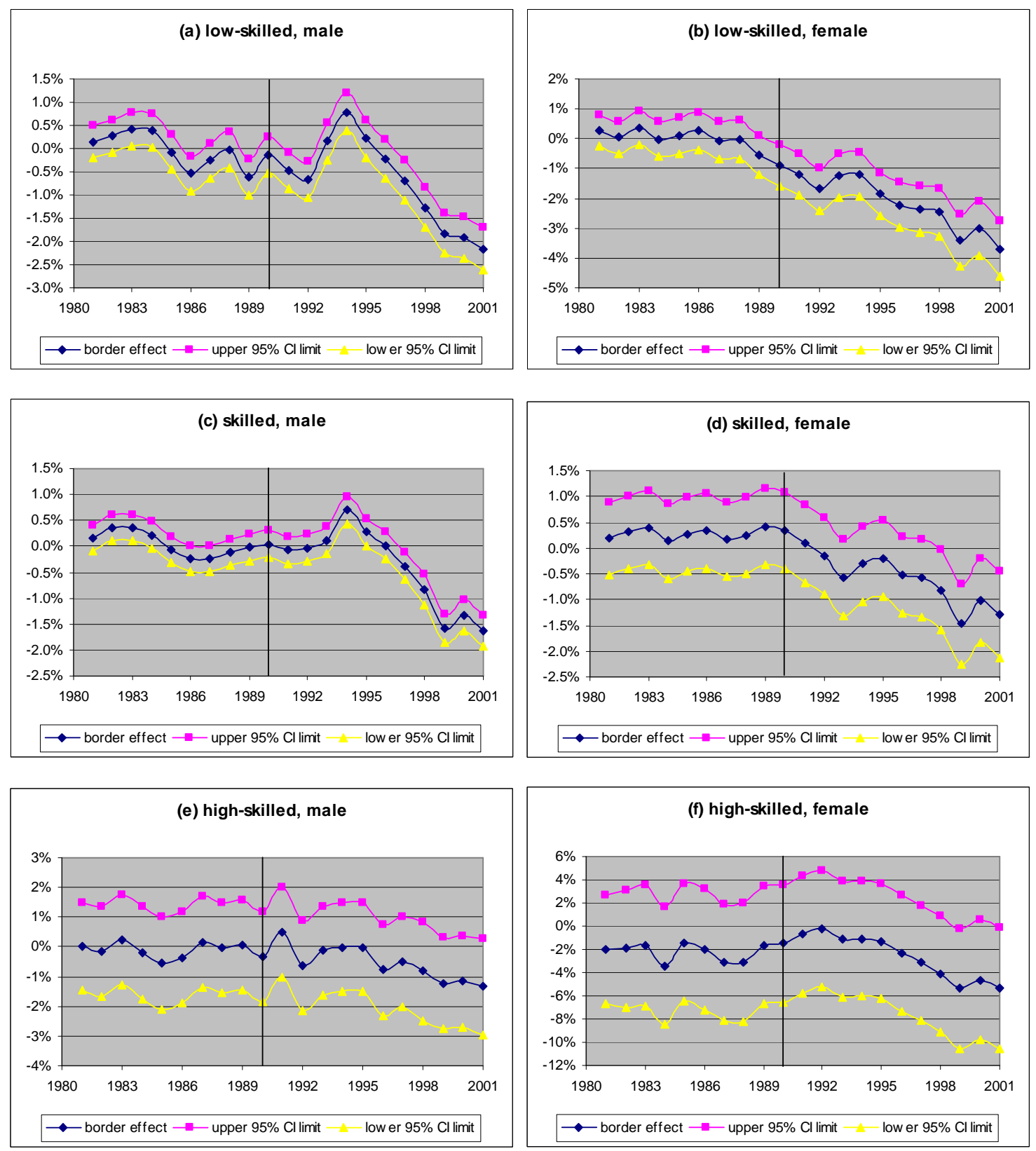

Figure 3: Fixed effects estimation: wage effect in eastern Bavaria (as \%, 1981-2001) Source: Own calculations using the weakly anonymous version of the IABS + BeH extract. 


\section{Conclusion}

The aim of this paper was to analyse the relative effects of the fall of the Iron Curtain on the eastern Bavarian borderland with respect to wage differentials. Therefor I compared the eastern Bavarian wage differential before the opening of the border in the 1980s to the years afterwards until 2001. According to the Feenstra-Hanson model international trade and outsourcing strikes the low-skilled workforce in the border region to a higher degree leading to relative wage losses. On the other hand, the higher attractiveness of the region after the abolition of trade impediments should benefit especially high-skilled employees. Regarding wage differentials between eastern Bavaria and the rest of western Germany I applied two estimation methods in order to identify the effects of the open border. In contrast to Moritz/Gröger (2007), which do not find significant results, a larger dataset and advanced methods shed more light on the changes. Using imputed wages and separating between male and female employees I estimate separate wage equations for every year and apply a fixed effects model. The estimates shed light on differences between male and female workers. For male lowskilled and skilled workers in the borderland, representing more than $60 \%$ of the eastern Bavarian workforce, a catching-up process can be verified until the mid 1990s. From 1995 onward the trend reverses and workers in the border region lose out relatively to employees in the rest of western Germany. The findings for all female skill groups and also male highskilled employees are not so clear-cut. The results of the fixed-effects estimation are most striking: for all sex and skill groups the wage gap deepens in the observation period. The question remains whether or not the opening of the border caused this development, and if so, why different skill and sex groups are affected in an unequal manner. After all, there is no change for the worse immediately after the opening of the border, the indications are actually quite positive in the early 1990s. However, from the mid 1990s or so onward the development in the border region gives cause for concern.

The results prompt the ongoing research on this topic. Since the observation period ends in 2001 the effects of the accession of the Czech Republic into the EU are not investigated in this framework. Moreover, free movement of labour is still restricted between Germany and the Czech Republic, i.e. the abolishment of tariffs and the full liberalisation of labour markets at the latest 2011 might cause deeper effects in eastern Bavaria. 


\section{References}

Airola, J., Juhn, C. (2005): Wage Inequality in Post-Reform Mexico, IZA Discussion Paper No. 1525, Institute for the Study of Labor (IZA), Bonn.

Bruno, G.S.F., Crino, R., Falzoni, A.M. (2004): Foreign Direct Investment, Wage Inequality and Skilled Labor in EU Accession Countries, Centre of Research on Innovation and Internationalization, Working Paper No. 154, Universita Bocconi.

Chiquiar, D. (2004): Globalization, Regional Wage Differentials and the Stolper-Samuelson Theorem: Evidence from Mexico, Working Paper 2004-06, Banco de México, Dirección de Investigación Económica.

European Commission (2001): On the Impact of Enlargement on Regions Bordering Candidate Countries. Community Action for Border Regions, Brussels, 25.7.2001.

Feenstra, R., Hanson, G. (1997): Foreign Direct Investment and Relative Wages: Evidence from Mexico's Maquiladoras, Journal of International Economics, vol. 42(3-4), pp. 371393.

Feenstra, R., Hanson, G. (1996): Foreign Investment, Outsourcing and Relative Wages, in: Feenstra, R., Grossman, G., Irwin, D. (eds.): Political Economy of Trade Policy: Essays in Honour of Jagdish Bhagwati, MIT Press, Cambridge, pp. 89-127.

Gartner, H. (2005): The imputation of wages above the contribution limit with the German IAB employment sample, FDZ Methodenreport 2/2005, IAB Nürnberg.

Geishecker, I. (2002): Outsourcing and the Demand for Low-skilled Labour in German Manufacturing: New Evidence, DIW Berlin Discussion Paper 313.

Geishecker, I., Görg H. (2003): Winners and Losers: Fragmentation, Trade and Wages Revisited, DIW Berlin Discussion Paper 385.

Hamann, S. (2005): Die regionale IAB-Beschäftigtenstichprobe IABS-R01, in: Grözinger, G., Matiaske, W. (Hrsg.): Deutschland regional - sozialwissenschaftliche Daten im Forschungsverbund, Rainer Hampp Verlag, München und Mering, S. 81-87.

Hanson, G. (1996a): Economic Integration, Intraindustry Trade, and Frontier Regions, European Economic Review, vol. 40(3-5), pp. 941-949.

Hanson, G. (1996b): U.S.-Mexico Integration and Regional Economies: Evidence from Border-City Pairs, NBER Working Paper No. 5425.

Mincer, J. (1974): Schooling, Experience, and Earnings, Columbia University Press, New York.

Moritz, M., Gröger, M. (2007): Labor market effects in the German-Czech border region - an empirical study using the IAB Employment Sample (IABS), Journal of Borderlands Studies, vol. 22 (2), pp. 57-76. 
Skuratowicz, A. (2005): Growing Wage Inequalities in Poland: Could Foreign Investment be Part of the Explanation?, ECFIN Country Focus, vol. 2(5), European Commission, Brussels.

Verbeek, M. (2004): A Guide to Modern Econometrics, $2^{\text {nd }}$ ed., John Wiley \& Sons, Chichester.

Wooldridge, J. (2003): Introductory Econometrics. A Modern Approach, $2^{\text {nd }}$ ed., Thomson South-Western, Mason/Ohio. 